\title{
Oil Exploration and Exploitation in Ugbo (Ilaje) Communities of Coastal Yorubaland
}

\author{
'Gbade lkuejube \\ Adeyemi College of Education Ondo, Nigeria \\ ajigbadejube@gmail.com \\ O. A. Funmilayo \\ Adeyemi College of Education Ondo, Nigeria \\ olukemiolabode@yahoo.com
}

\begin{abstract}
Coastal Yorubaland is one of the richest parts of Nigeria in terms of natural resource endowment. The area is blessed with extensive forests, good agricultural land and abundant water resources such as fish. It is also blessed with reserves of crude oil. This natural resource has attracted the attention of oil companies, whose activities often result in economic and social problems such as environmental pollution, occupational dislocation, cultural extinction and rural urban drift. However, the attitude of the people in this region, especially the militant youths, has also contributed to environmental degradation: oil pipe vandalization has become a constant occurrence, and it has a debilitating effect on the environment. Environmental devastation, economic poverty and constant conflict constitute a lived reality. Oil exploitation activities have also left much of the area desolate, poor and uninhabitable. This article argues that the effects of oil exploitation on Ilaje Ugbo communities are comparable to what occurs in other oil communities of the Niger Delta region of Nigeria.
\end{abstract}




\section{Introduction}

The coastal part of Yorubaland is one of the richest regions of Nigeria in terms of natural resources endowment. In the Ugbo (Ilaje) area, there are large crude oil and gas deposits, extensive forests and abundant fish resources. However, the area has remained poor and underdeveloped. Meager living conditions are exacerbated by serious ecological devastation and damage arising from oil production. This has left much of the Ugbo (Ilaje) communities desolate, poor and uninhabitable. The Nigerian government and the multinational oil companies operating in the area have made little or no effort to control the environmental problems associated with oil exploration and exploitation.

Oil exploration in the Ugbo communities began in the 1970s, but the scale of operations increased when Chevron, formerly known as Gulf Oil, secured exploration licenses to operate in the area in 1980s. ${ }^{1}$ Today, Chevron is in partnership with other subsidiaries and in this capacity has been extracting several thousand barrels of oil per day from different Ugbo communities. Originally oil exploration began in the following Ugbo communities: Ubale, Molutehin, Odun-Igo, Uba-Jakere, Ebighan, Oghoye, Ojumole, Ajegule, Bowoto, Rewoye, Awoye, Odofado, Ogungbeje, Odun-Oyinbo, Odonla, and Odun-Oretan. ${ }^{2}$ However, recently oil exploration activities have extended to other Ugbo communities and take place on several oil fields. In addition to Chevron, five other national and multinational oil companies operate in Ugbo. These are Shell Petroleum Development Company, Cronicle, Express Oil, Consolidated Oil and Allied Energy. ${ }^{3}$

There is no doubt that the Nigerian state and oil multinationals have made significant profits from exploiting oil in the Ugbo communities. The profits are buttressed by government legislation that deprives the people from right or access to communal land, while the oil companies have unrestricted access to explore oil unchallenged, even on sacred land, as long as they have government permission. The manner in which the people's rights have been undermined has provoked a series of conflicts between companies and the government and also between communities and oil companies in the area. ${ }^{4}$ Besides

1. B.A. Omogbem, Ilaje Nation and Her Cultural Heritage (Ondo: Grace Excellence Publishers, 2007).

2. G Ikuejube, Ugbo People of Coastal Yorubaland (Ondo: Novec'kol Printer and Publisher 2006).

3. J.A.B. Olujimi, A.A. Emmanuel and O. Sogbon, "Environmental Implications of Oil Exploration and Exploitation in the Coastal region of Ondo State, Nigeria: A regional Planning Appraisal," Journal of Geography and Regional Planning, 4.3 (2011).

4. G. Ikuejube, "Oil Exploitation and Inter Ethnic Hostilities in Nigeria: Implications for national Security," in J.S. Babatolu and Gbade Ikuejube, eds., National Security and Re- 
the incessant conflicts it has occasioned, oil exploitation also had significant impact on the physical environment of the oil bearing communities, and in particular on threatening the traditional fishing economy of the people in the waters beyond the coastline.

Nigeria's oil producing communities are experiencing environmental stress as a result of human activities and actions at various stages of minerals and oil business activities, including prospecting, drilling, production, refining and distribution. ${ }^{5}$ Some quantities of oil are released into the environment during oil exploration, storage, processing and distribution as a result of operational accidents, equipment failure and other reasons. ${ }^{6}$ The resultant effect of this is environmental pollution.

\section{The Study Area}

Coastal Yorubaland is situated in the riverine area of Southwest Nigeria, bordering on the Atlantic Ocean. The Ilaje area, which forms part of Coastal Yoruabaland, lies roughly between latitude $6^{\circ} \mathrm{N}$ and $6.30^{\circ} \mathrm{N}$ and longitude $4.35^{\circ} \mathrm{E}$ and $4.45^{\circ} \mathrm{E} .^{7}$ The land is bounded to the north by the Ikale and Ijaw and to the south by the Atlantic Ocean, to the west by the Ijebus and to the east by the Itsekiri. The Ilaje area includes two distinct forms of land. The northern parts are comparatively drier and higher than the swampy land of the south. But even on the low land belt, the dark and humid surroundings are interspersed with vast stretches of dry land. ${ }^{8}$

Ugbo (Ilaje) communities form a part of Ilaje Local Government Area of Ondo State, Nigeria. Most coastal Yoruba people build their houses on stilts, partly because of the swampy nature of the terrain during the wet or rainy season, when the land area is usually flooded. Between the black mud of the beach and the forest swamp there is a narrow strip of a lower-lying or submerged swampy area. It is crisscrossed by creeks which facilitate most transportation in the area. ${ }^{9}$ Transportation is largely restricted to the use of canoes

sources Management in Nigeria (Ibadan: Alafas Nigeria Company Limited, 2011), 22-29.

5. S. O. Aghalino, "Petroleum Exploitation and Agitation for Compensation by Oil Producing Communities in Nigeria," Geo Studies Forum, 1.2 (2000): 11-20.

6. L. T. Ajibade and A. A. Awomuti, "Petroleum Exploitation and Human Exploitation: An Overview of Niger Delta Oil Producing Communities in Nigeria," African Research Review 3.1 (2009): 111-124.

7. Ilaje/Ese Odo Local Government Brochure, 1988.

8. Ibid.

9. G. Ikuejube, Ilaje: The Yoruba fishing people of the Niger Delta (Ondo: Novec'kol Printer and Publisher, 2005). 
and power engine boats. There are many rivers which are navigable and therefore support the people's occupation of inland fishing. Apart from fishing the people practice crop cultivation on the banks.

Prior to the discovery of oil in Ugbo communities of Coastal Yorubaland, the people were mainly fishermen. Many of the inhabitants continue to rely on fishery and other aquatic businesses as their major source of livelihood. The people also engage in agricultural activities at the bank of the rivers where food crops were grown. According to Babatunde, there are other activities that are income generating for the oil producing communities and these include forest products like timber and non-timber forest products. ${ }^{10}$ Timber is used for canoe and paddle carving while non-timber forest products such as bamboo and raffia palm are used for the production of fishing gears, local gin and wine.

Today, infrastructure and services such as roads, electricity, potable water, education, health facilities and information are at low levels. ${ }^{11}$ The number of secondary schools remains low, but even for those who have left school, there is little appropriate employment because the formal sector is almost nonexistent. The decrease of their life chances, without adequate compensation by the government or the oil companies, has pitched many local people against the state and its industries.

\section{Effect of oil exploration and exploitation on the environment}

It is perhaps ironic that the people of the coastal areas, whose land and water produce the bulk of oil that generates income and wealth for Nigeria, are battling with frustrations arising from untold hardships bestowed on them by the oil companies on one hand and the Nigerian political class on the other hand. Most important among these hardships are the contamination and pollution of surface water and river courses, which rendered drinkable water unsafe for drinking and caused the death of local aquatic life. ${ }^{12}$ Besides, owing to sea incursion occasioned by oil exploration, formerly sweet water areas have turned salty.

10. A. Babatunde, "The Impact of Oil Exploitation on the Socio-Economic Life of the Ilaje-Ugbo People of Ondo State," Journal of Sustainable Development in Africa, 12.5 (2010): 61-82.

11. L. K. Jeje, and F.A. Adesina, Man and Environment: An Introductory Note (Ile- Ife: Joakem Enterprises Global Concept Limited, n.d.).

12. G. Ikuejube, Ilaje: The Yoruba Fishing People of the Niger Delta (Ondo: Novec'kol Printer and Publisher, 2005). 
In many cases, the victims of environmental pollution have been forced to migrate away from communities where fishing was no longer productive. As the water of the Atlantic recovers more quickly from oil spillages than the narrower creeks inland, many migrants from inland towns have moved to new settlements directly on the Atlantic coast, where they have richer fishing grounds. However, as the sea water is not potable, such settlements are often more expensive to maintain as drinking water needs to be brought in from elsewhere.

Oil extraction and production has also led to adverse environmental impact on the soil and forest areas of coastal Yorubaland. Various harmful and toxic organic compounds, when introduced into the natural environment during oil extraction, have negative repercussions on the geo-chemical composition of the soil. Several farm lands and multiple species of coastal fauna were lost to oil spillage in the region. ${ }^{13}$ As a result, agricultural output has declined as well. Again, this process has encouraged migration.

Oil spills have become a common phenomenon in the Niger Delta since the discovery of crude oil in the region. According to the Department of Petroleum Resources (DPR), between 1976 and 1996 a total of 4,647 incidents of oil spillage occurred in the Niger Delta. ${ }^{14}$ Available records indicate that approximately $5 \%$ of total oil spilled in the Niger Delta affected Ugbo communities. For instance, a study by Nwilo and Badejo revealed that a large oil spill that occurred in Idoho in Akwa Ibom (Eastern Niger Delta region) travelled all the way from Akwa Ibom State to Lagos State, dispersing oil through the coastal states up to the Lagos coast. This culminated in the presence of sheen oil not only in Ugbo communities but other coastal communities in Delta State, Ondo State and even Lagos State. ${ }^{15}$ Some major spills in the Niger Delta which affected Ugbo communities were the Escravos spill and the Shell Forcados terminal tank fire; other oil spill incidents are those of Ugbo-Kaba and Koko.

Since the major occupation of the Ugbo people is fishing, the occurrence of spillage at any time jeopardized their means of livelihood as fishing materials were damaged and fishes were poisoned. After every spill, many fishermen could not work for months, and this had a negative effect on the inland fishing business in the region more generally. Following every spill, there was reduction in catch and quantity of fishes and other water-based animal protein, such

13. J.A.B. Olujimi, A.A. Emmanuel and O. Sogbon: "Environmental Implications of Oil Exploration and Exploitation in the Coastal region of Ondo State, Nigeria: A Regional Planning Appraisal," Journal of Geography and Regional Planning 4.3 (2011).

14. A. Agho, "Oil of poverty in the Niger Delta," African Network for Environment and Economic Justice, XI.2 (2007).

15. C. Nwilo \& B. Badejo, "Oil spill problems and management in Niger Delta," International Oil Spill Conference, Miami, Florida, 2005. 
as crabs, available in the major markets such as Aiyetoro market, Atijere market and Igbokoda market.

Oil spills in the region have been a regular occurrence and the resultant degradation of the surrounding environment has caused significant tension between the Ugbo people and the multinational oil companies operating in the area. This has led to the foundation of pressure groups such as Ilaje Environmental Right Association, the Ilaje Niger Delta Congress of Nigeria and Ugbo central organization. ${ }^{16}$

Another major effect of oil exploitation is that each round of environmental degradation tends not only to increase the incidence of poverty among vulnerable groups, but also involves intensified pressure on other existing natural resources. For example, a particular kind of despoliation results from the removal of the earth from the areas surrounding production wells and its deposition in areas not identified as private farmland but used for hunting an vegetable collection.

Because of the toxic nature of such earth, these deposits affect the immediate environment, namely the local plant and animal life. As a result, the area cannot be used by people to supplement their diets and incomes. Because soil degradation in the region has deleterious effects on forest resources, it also affects those relying on timber and non-timber forest resources for their livelihood. In particular, the area has seen a reduction in mangrove species. ${ }^{17}$

Finally, the communities in coastal Yorubaland continue to lose human lives as a direct consequence of oil exploitation. Again, many of those losses are caused by environmental pollution and leakages of the oil pipeline. As local water, fish, and agricultural produce may be contaminated by crude oil, some individuals fall ill through consumption, while others are affected because oil vapors irritate their lungs, eyes, and skin. While there is no detailed local health data available, anecdotal evidence points to high rates of asthma, general weakness, and cancer.

\section{Ugbo responses to environmental degradation}

Nigeria's political elites either deliberately or inadvertently ignore both the environmental hazards that result from oil exploitation, and the resulting problems affecting the local population. As a result, many people see them-

16. Ikuejube, The Yoruba Fishing People of the Niger Delta.

17. Bayode, Olujimi Julius Ajilowo, and Emmanuel Adebayo Adewunmi. "Environmental implications of oil exploration and exploitation in the coastal region of Ondo State, Nigeria: A regional planning appraisal." Journal of Geography and Regional Planning 4, no. 3 (2011): 110-21. 
selves as being exploited and marginalized by government and the various multinational oil companies operating there. The indifference of the state and the oil companies have provoked various forms of reaction, some bordering on criminality, while others are borne out of genuine feelings of resisting injustice, marginalization and oppression.

The neglect of these oil producing communities has often angered the militant youths which resulted in their venting of anger on oil companies personnel and the vandalization of pipelines. Local protest included the seizure of oil wells, equipment and equipment of oil companies, the paralyzing of oil drilling activities, and the vandalization of pipelines and other oil installations.

Confronted with these types of action, the Nigerian State has often resorted to force in order to silence the people. Having endured the repressive approach for decades, many people are, however, now damning the consequences and demand state investment, which they see as their rightful compensation for the natural endowment given to them by God. ${ }^{18}$ According to Ibaba, the protests have been stepped up in recent years to include the kidnapping of company workers, particularly the expatriate workers, and the rough handling and even killing of state security operatives in the region. ${ }^{19}$

The crisis in the region continues to linger on both because of the lack of commitment to resolve the crisis by government and because of the uneven way in which different communities are compensated for the damage suffered after oil spills. ${ }^{20}$ As a result of the misunderstandings arising from disputes over compensation among different oil producing communities, some Ilaje people have formed associations to represent their interests vis-à-vis neighbouring groups, such as the Ijaw. Unlike some associations in the Niger Delta, these associations are not destructive in their agitation for improved living conditions but struggle non-violently for the political, economic and environmental rights of the people.

18. A.I. Moro, Socio-Political Crisis in the Niger Delta (Ibadan: Spectrum Books Limited, 2009).

19. S.I. Ibaba, "Oil and Political Consciousness in the Niger Delta," Nigerian Journal of Oil and Politics, Special Edition (2003): 79-90.

20. H.B. Erezene, "Continued Crisis in the Niger Delta: Implications for National Security and Resource Management in Nigeria," in J.S. Babatolu and G. Ikuejube, eds., National Security and Resource Management in Nigeria, (Ibadan: Alafas Nigeria Company Limited, 2011), 8-21. 


\section{Intergroup relations and environmental degradation beyond the Ugbo communities}

Oil spillage has also had devastating effects on relations between the Ugbo communities and neighboring non-oil producing communities in coastal Yorubaland, and even among the Ilaje. In most cases, compensation regarding oil spillage is only paid to the Ugbo communities where the spillage originally occurs, but not to the communities that are also affected by it. But as we have set out above, the effects of oil spillage are not usually limited to one locality, and can be far-reaching. This means that in many communities, especially towards the west of Ugboland, which are not classified as oil-producing, people go through environmental and psychological trauma whenever oil spillage occurs, yet no compensation is paid to them.

Closely connected to the above is the discrimination against the non-oil producing communities in Ilajeland in the appointment of representative to oil commissions. ${ }^{21}$ The oil commissions are created by the Federal and State Governments in recognition of the contribution of oil to the national economy. The commissions are empowered to rehabilitate and develop the oil producing areas of Ondo State (and elsewhere) and to carry out developmental projects determined to be appropriate. Since the establishment of various oil commissions, the non-oil producing communities of Ilajeland have been denied adequate representation. The non-oil producing communities became uncomfortable with this arrangement because they perceived the Ugbo communities as seeing their neighbors as people who were meant to be seen but not heard as far as oil politics was concerned. The determination of the Ugbo to prevent other communities in Ilajeland from representation in the oil commission led to resentment and further fueled conflict between Ugbo and her neighbors.

Today, it is clear that the relationship between Ugbo and her neighbors is characterized by mutual suspicion, rivalry, intimidation, jealousy and victimization. These manifest in many facets of interaction, for example on market days. Despite this ugly development, the conflict has not escalated into violent conflict. The maintenance of peaceful relations has been supported by the activities of Ilaje Youth Forum, the National Association of Ilaje students and Egbe Omo Ilaje, who are responsible for peace building and the total reconciliation of all the aggrieved parties in Ilajeland as a result of oil exploitation in Ugbo. These organizations hold periodic meetings and develop new strategies

21. G. Ikuejube, "Ugbo-Mahin Conflict in Ilaje, Ondo State," in I. O. Albert, ed., A History of Social Conflict and Conflict Management in Nigeria (Ibadan: John Archers Publishers Limited, 2012). 
to entrench interaction and share experiences. Furthermore, the Olugbo of Ugbo and other traditional rulers in Ilajeland continue to mitigate several potential conflict situations that could escalate into violent crises. They have, through their activities, demonstrated commitment to peace-building. Their campaign against violence has so far yielded considerable results.

However, in spite of the efforts of these associations and the traditional rulers, who arguably are now well disposed to peace, many issues still remain outstanding and require greater attention and commitment by all, to ensure lasting and sustainable peace between Ugbo and her neighbors. These include the marginalization of the non-oil producing communities in the compensation for oil spillage and other ecological problems occasioned by the oil exploration and exploitation in Ugbo and the discrimination against Ugbo neighbors in the appointment of representatives to the Niger Delta Development commission (NDDC) and Ondo State Oil Producing Areas Development Commission (OSOPADEC). Other issues include the prevention of youth from non-oil producing communities from enjoying oil companies' scholarships and empowerment programs targeted at Ugbo communities only. Sadly there are also associations in Ilajeland which are motivated or nourished by ethnic chauvinism and parochialism.

\section{Conclusion}

The negative economic impact of oil exploitation has led to social and political unrest in the coastal areas. As we illustrate above, physical infrastructure and social amenities exist only to a low degree, and human health and welfare are being threatened on daily basis as a result of pollution, most importantly the scarcity of renewable fresh water. As elsewhere in the delta, this contrasts bitterly with the benefits derived from oil production by the oil companies and the local state.

\section{Bibliography}

Babatunde, A. (2010). “The impact of oil exploitation on the Socio-Economic Life of the Ilaje-Ugbo people of Ondo State." Journal of Sustainable Development in Africa 12.5 (2010): 61-82.

Ebegbulem, J.C., D. Ekpe, and T.O. Adejumo. "Oil Exploration and Poverty in the Niger Delta Region of Nigeria: A Critical Analysis.” International Journal of Business and Social Science 4.3 (2013): 279-287.

Ikuejube, G. Ilaje: The Yoruba fishing people of the Niger Delta. Ondo:

Novec'kol Printer and Publisher, 2005. 
Ikuejube, G. Ugbo People of Coastal Yorubaland. Ondo: Novec'kol Printer and Publisher, 2006.

Omogbemi, B.A. Ilaje Nation and her Cultural Heritage. Ondo Grace Excellence Publishers, 2007. 